\title{
The Disappointed of Economic Assistance in Aceh: Study Disempowerment of the Former Free Aceh Movement's Widow
}

\author{
Ristati M. Yahya, Khairawati M. Hanafiah, Nurlela Ima Abdullah ${ }^{1 *}$ and Zulham Ibrahim $^{2}$ \\ ${ }^{1}$ Department of Management,Universitas Malikussaleh, Lhokseumawe, Indonesia \\ ${ }^{2}$ Department of Political Science, Universitas Malikussaleh, Lhokseumawe, Indonesia
}

\begin{abstract}
The ancient conflict in Indonesia's regional history has been ended, particular between the Free Aceh Movement (Gerakan Aceh Merdeka $(G A M)$ and the central government. Since the peace took place in the region in 2005, it doesn't mean that all social aspect has covered up peacefully. In the beginning, the peace talks aimed at ensuring the economic recovery for all who have been victimized from the conflict. In fact, there is still remained dispute within society, specially, among Acehnese, such as economic empowerment of the former Free Aceh Movement's widows, who were part of the conflict victimized; so far their economic life stays under developed. Thus, this research objective tries to address the above backwardness phenomenon. The methodology used is qualitative approach, in which the data is collected through field works by interview. The result of the study concludes that the widow of the former free Aceh movement keeps remained forgettable from the local economic development. It is approved by no any single assistance from Aceh government as well as member of Aceh legislature surrendered to them. Although, there is some assistance, unfortunately, it does not resolve their economic livelihood. ${ }^{1}$
\end{abstract}

\section{Introduction and literature review}

GAM is an organization declared by Hasan Tiro in 1976 as a form of disappointment caused by the central government that embraces centralism. Meanwhile, Aceh has supported Indonesia's struggle to face the Dutch in order to maintain independence. Aceh also contributed a considerable contribution, even referred to as the capital area of the Republic of Indonesia by Soekarno [1]. The tsunami has shaken the world and one of the first major disasters that killed many victims at the beginning of the third millennium. This earthquake invited a lot of solidarity and humanitarian sympathy throughout the world. Since that time, Aceh has been known in international scenarios and this is a matter of internal conflict becoming more open where atrocities have occurred almost three decades in the province [2].

The United States, European Union, Japan, Australia and ASEAN member countries will assist the Aceh region to resolve conflicts and tsunami victims as well. These countries have

\footnotetext{
*Corresponding author: ristati.tati82@gmail.com
} 
a commitment to fund Indonesia at least US \$ 150 million to support peace in Aceh, exceeding and above billions of dollars committed to tsunami relief and reconstruction [3]. None the less, some non-traditional donors such as China and North Korea contributed to providing assistance on a unique scale in a devastated disaster [4]. After peace created between the Government of Indonesia and the Free Aceh Movement, the main priority is to prosper the victims of the conflict. Empowering the widows of the former Free Aceh Movement is an important agenda. This empowerment process can only be done if all GAM fighters have a great desire to participate in the reintegration program. According to the United Nations, reintegration is an act of assistance given to former combatants that will increase the economic and social potential of their families and social integration into civil society [5]. The concept of "reintegration" is most commonly used in post-conflict situations where rebel fighters live long periods in military camps far from their communities. In some cases, commanders have tied new members to their units by forcing them to commit atrocities against their own villages. Reintegration in this context aims to improve social relations between fighters and their communities, and to help ex-combatants build a livelihood during peace [6]. In Aceh, reintegration must be a process to assimilate demobilized personnel into the economy, social and political life of civil society. This includes various actions targeted at GAM ex-combatants, including vocational training and formal schools, micro-credit schemes and a return scheme for housing, medical care counseling, incapacity and involvement in community organizations [7]. In the initial peace process, GAM was ambivalent with the concept of reintegration, arguing that these members were never disclosed from their communities and therefore did not require 'reintegration'. Instead, GAM members saw themselves as defenders of the Acehnese community [8].

\subsection{Social Empowerment}

Community empowerment can be interpreted as an effort to restore or enhance the empowerment of a community to be able to act in accordance with their dignity in carrying out their rights and responsibilities as a human community and citizens. The ultimate goal of community empowerment is the recovery of human values according to their dignity as a unique, independent and independent person. Unique in the context of human diversity; independence from all internal and external shackles including the bonds of worldliness and poverty; and independent to be able to be a programmer for himself and responsible for himself and others [9]. Community empowerment is a development paradigm that prioritizes wider data for the community in the development process. The paradigm of empowerment and development is the same part (model) of the implementation of social change theory. Nevertheless, in the reality order there is a gap that separates between theoretical and academic circles with empowerment or development practitioners who work with marginal communities, such as workers, farmers, fishermen, neglected children, and indigenous peoples in various regions. 3 Theoretical and academic think in the level of objective and ideality, while development practitioners who are supported by political elites and or the government and capitalists are influenced by capitalism that seeks to take maximum advantage. In fact, the theory used is a theory that supports vision of capitalism [10]. According to Ife empowerment contains two key meanings, namely power and weak groups. Power here means not only political power in the narrow sense, but the power or control of the client over: 1 . Personal choices and opportunities for life, the ability to make decisions about lifestyle, residence and work. 2. Defining needs, the ability to determine needs in line with their aspirations and desires. 3. Ideas or ideas, the ability to express and contribute ideas in a forum or discussion freely and without pressure. 4. Institutions, the ability to reach out, use and influence community institutions such as social welfare, education and health institutions. 5. Resources, the ability to mobilize formal, informal and social resources. 6. 
Economic activity, the ability to utilize and manage the mechanism of production, distribution and exchange of goods and services. 7. Reproduction, ability in relation to the birth process, child care, education and socialization [11]. There are 4 concepts of economic empowerment according to Sumodiningrat (1999) as quoted by Mardi Yatmo Hutomo, in brief can be stated as follows: a. The people's economy is an economy organized by the people. The economy held by the people is a national economy that is rooted in the potential and strength of society at large to run their own economic wheels. b. People's economic empowerment is an effort to make a strong, large, modern and highly competitive economy in the right market mechanism. Since the constraints of developing people's economy are structural constraints, the empowerment of people's economy must be done through structural changes. $c$. The structural change in question is a change from the traditional economy to the modern economy, from the weak economy to the strong economy, from the subsistence economy to the market economy, from dependence to independence. People's economic empowerment is not enough just by increasing productivity, providing equal business opportunities, and only giving capital injection as a stumulant, but there must be a close collaboration and partnership between those who have advanced and those who are still weak and underdeveloped [12].

\section{2. Gender Empowerment}

Women's empowerment is an effort to improve women's ability to develop women's capacities in order to be able to gain access and control over, among others: 1. Position of decision making, 2. Resources, 3. Supporting structures or pathways. This process of women's empowerment can be carried out through awareness. With this awareness, women are expected to be able to critically analyze the situation of the community so that they can understand / know the discriminatory practices which are social constructs and differentiate the roles between natural and spiritual roles. Therefore, for women in the awareness process, they need to be left with information, education, and motivation to get to know their identity and be more confident and be able to take the necessary decisions [13].

\section{Objective of the study}

This study aims to investigate the authors to understand the economic recovery for all who have been victimized from the conflict. In fact, there is still remaining dispute within society, specially, among Acehnese, such as economic empowerment of the former free Aceh Movement's widows, who were part of the conflict victimized; so far their economic life stays under developed.

\section{Methodology}

The in-depth interviews help the authors to understand the thoughts and explore relevant issue in depth. The purpose of in-depth interviewing is to get answer to questions, and to understand their economic empowerment and disempowerment specifically in the period of Aceh post conflict. The author interviewed the widows - Mrs. Sumarni H. Ismail, Mrs. Darmawati, Mrs. Asmaul Husna, Mrs.Nidarwati and Mrs. Ainiah respectively at different times. Moreover, the research uses qualitative approach, which is collecting data from the literature related to phenomena being discussed, and then analyzing it. This literature in the form of books, documents, journals and internet sites related to the problems studied [14]. In the first stage, the researcher collects all the materials that the authors discuss. Then make notes on the collected material. These notes are then called bibliographic notes [15]. 
Furthermore, the data obtained from the references are analyzed descriptively. Where the process of data analysis is done after the authors reduce the existing data. Reduction is an analysis that sharpens, categorizes, directs, data in such a way that the final conclusion can be drawn. The authors also interpret the data that has been reduced, so that the data can be explicitly designed into a research result, where the results have been written down in conclusion.

\section{Discussion}

The Helsinki agreement between Indonesia government (RI) and GAM greatly prioritizes the alleviation of poverty and economic inequality in Acehnese society. Poverty reduction includes several elements, parties where those who will be eligible to receive aid in the form of financial or physical assistance, house building and land distribution for example. The elements covered are those who are involved in the conflict, those who are affected by the conflict both directly and indirectly. Direct involvement in the conflict arena of excombatants of the Free Aceh Movement meant that those who actively used weapons at that time, the Indonesia military and police (TNI / POLRI) were also included in the economic program. Some argued that they who were pro-Indonesian paramilitaries during the conflict were also to be treated as parties who can receive economic assistance and funds.

Indirect elements affected by this riot, is defined such as civilians who do not use weapons and are not involved in the conflict, those who are physically and non-physically injured, for example, houses are burned by irresponsible parties or persons and those who hit by bullets and other sharp tools during a fight. Gender is also a major element in economic recovery programs. Gender includes women who suffered from losses due to conflicts both material and non-material damages, particularly the widow of the former independent Aceh (GAM) movement in which, their home or other property is injured during the conflict and their victim's family, such as the death of the husband and her relatives from the conflict. In general, victims of conflict is regardless of tribes, races and religions, all of whom experience direct and indirect impacts from the conflict, even though they are not from the Acehnese tribe, they are eligible to receive compensation from the central government through the local government.

This economic empowerment is distributed through a jointly formed agency on the agreement of all parties, namely the Aceh Reintegration Agency (BRA). Beside the central in the city of Banda Aceh, this agency also has sub-divisions in the area or often called Regency/City BRA. This legal body distributes the financial assistance submitted by the central government to be distributed to parties who have been categorized as victims of the conflict. After the funds were disbursed from the center to the provincial BRA, then the provincial BRA distributed them to all regions through the respective BRA Regencies/Cities. At the beginning of the implementation of aid distribution, it is expected that the funds can be used to improve people's economy, as capital for businesses and other purposes. Therefore, citizens can improve the economy that was once collapse during the conflict period and they can live more established from their economic assistance. In fact, unfortunately there are many obstacles found in the field. Both from the technical constraints of distribution, the accuracy of the data that is feasible to receive assistance and the number of amount received in the field by the citizens. The utilization of the use of aid funds is not appropriate on target by the recipients. The combination of all these aspects then made the snowball as well as a new problem in Aceh that has just recovered from a prolonged armed conflict.

The Aceh Reintegration Agency (BRA) has faced a crisis of trust; the community indicated that there was discrimination in distributing aid for economic empowerment funds. Those who received the funds are those who only assumed close to BRA. The ordinary 
citizens who had the right to receive but no access to BRA did not receive any assistance. BRA as the agency, which is in charge in the regional district, argued that they did not receive the number of funds which is promised by the central government. Data is another problem that slows down economic empowerment in post-conflict Aceh. The complexity of the data collection process in the field to classify those who are eligible to receive economic aid funds is increasingly enlarged in number. All residents in the city claimed that they were victims of the conflict and had the right to receive the compensation. This dilemma worsens the actual data collection. Therefore, the Aceh government tries to cover all the elements claiming to be victims of the Aceh conflict. This accommodation process has implications for the reduction of the amount of funds that will be received by the victim, where a victim will be able to receive a total of five million rupiahs, so with the increase in victim data, he will only receive two million and even one million. Looking at these dynamics phenomena, the economic empowerment efforts are still running in place, as well as the current economic conditions as before.

The people (widows) justified that they could do nothing from the very small funds they received. It is not sufficient, neither to eat, nor to daily needs, it is far from enough. The economic condition of the widows in Aceh is difficult for acceleration; the fact factor is that not only due to available financial but the lack of human resources factor also greatly influences it. In the Post-conflict, Aceh does not merely stand on conflict aid funding, but in its empowerment, Aceh receives oil and gas revenue sharing funds, regional autonomy funds (OTDA), special autonomy funds (OTSUS). Huge number of fund circulation in the region, but the people's economy is still below 1.8\% while compared to the conflict in Aceh $1.1 \%$. There are a few changes indeed, but the increase is not very significant. It means that the number of poor people is still high in Aceh.

\section{Conclusion}

The above study shows that the empowerment and economic assistance for women widows of GAM are very few, they are no longer paid attention to by their local government and to care their needs. As one of the core objective of peace point between the Indonesian government and the Free Aceh Movement is to empower them. GAM is no longer in line with its original goal of empowering widows of conflict victims. It is stated in the preliminary agreement, namely the MOU's agreement to protect women. The above discussed data is very clear about their economic marginalization and economic disempowered.

\section{References}

1. Serambi Insonesia, Edisi 22/05/2008.

2. H. Kawilarang, Aceh dari Sultan Iskandar Muda ke Helsinki. (Bandar publishing, Banda Aceh, Indonesia, 2008).

3. B. A. King, Peace in Papua: widening a window of opportunity. (The Center for Preventive Action. Council on Foreign Relations, United States of America, 2006).

4. Gaillard, J. C. Gaillard, E. Clave and I. Kelman, Wave of peace? Tsunami disaster diplomacy in Aceh, Indonesia. Geoforum 39, 1, Pp 511 - 526, Doi:10.1016/j.geoforum.10.010., (2008).

5. T. R. Shie, Disarming for Peace and Development in Aceh. Available at: http://www.acehrecoveryforum.org/library/download.php. (2004).

6. ICG, Aceh: post-conflict complication. Asia Report No. 139, 4 October. (ICG, Jakarta/Brussels, 2007).

7. A. Widjajanto. Initiating security sector reform for Aceh. (Jakarta Post, Jakarta, 2003) 
8. L. Frodin, The challenges of reintegration in Aceh. In Aguswandi \& Judith Large (Eds.), Accord, Issue 20. Reconfiguring politics: the Indonesia - Aceh peace process. (Conciliation Resources, London, 2008).

9. E. F. Harahap, Pemberdayaan Masyarakat Dalam Bidang Ekonomi Untuk Mewujudkan Ekonomi Nasional Yang Tangguh dan Mandiri. Jurnal Manajemen dan Kewirausahaan, JMK 3, 2, Pp 78 - 96 (2012).

10. Faizal, Diskursus Pemberdayaan Masyarakat, Ijtimaiyya 8, 1, Pp 52-66 (2015).

11. E. Suharto, Membangun Masyarakat Memberdayakan Rakyat: Kajian Strategis Pembangunan Kesejahteraan Sosial dan Pekerjaan Sosial. (Refika Aditama, Bandung, 2009).

12. N. Martono, Sosiologi Perubahan Sosial: Perspektif Klasik, Modern, Posmodern, dan Poskolonial. (Rajawali Press, Jakarta, 2011).

13. T. O. Ihromi, dkk, Penghapusan Diskriminasi Terhadap Wanita. (PT. Alumni, Bandung, 2006).

14. M. Kasiram, Metodelogi Penelitian, Refleksi Pengembangan Pemahaman dan Penguasa Metodelogi Penelitian. (UIN Press, Malang, 2008).

15. S. Arikunto, Prosedur Penelitian, suatu Pendekatan Praktek. (PT Rinekecipta, Jakarta, 2002). 